\title{
АГРОЕКОЛОГІЧНА ТА ЕКОНОМІЧНА ОЦІНКА ЗАСТОСУВАННЯ ГРУНТОВИХ І СТРАХОВИХ ГЕРБІЦИДІВ ПРИ ВИРОЩУВАННІ КУКУРУДЗИ НА ЗЕРНО В УМОВАХ ЛІВОБЕРЕЖНОГО ЛІСОСТЕПУ УКРӒ̈НИ
}

\author{
О.С. Дем'янюк \\ доктор сільськогосподарських наук, старший науковий співробітник \\ Інститут агроекології і природокористування $Н A A H$ \\ (Україна, м. Київ; е-mail: demolena@ukr.net) \\ Д.О. Шацман \\ здобувач \\ Інститут агроекології і природокористування НААН \\ (Україна, м. Київ; e-mail: dmitry@evrosem.com)
}

Визначено агроекологічну оиінку та економічну ефективність вирощування кукурудзи на зерно за беззмінного посіву за різних систем захисту рослин, проаналізувати економічні показники й структуру виробничих витрат. В умовах Лівобережного Лісостепу України в технологї беззмінного посіву кукурудзи на зерно визначали еколого-економічну очінку внесення грунтових (Харнес, Стомп 330) і страхових (Каллісто 480 SC, Мілагро 040 SC, Діанат, Естерон 60) гербічидів. Розраховано ступінъ небезпеки застосування гербіиидів та агроекотоксикологічний індекс за санітарно-гігієнічними й екотоксикологічними показниками. Розраховано показники економічної еффективності технологій вирощування кукурудзи на зерно за різних систем захисту рослин. 3 а сукупністю екотоксикологічних і санітарно-гігієнічних показників препарат Харнес зараховано до небезпечних препаратів, препарати Стомп 330, Каллісто 480 SC, Мілагро 040 SC, Діанат, Естерон 60 - до помірно небезпечних. Застосування гербічидів за беззмінного посіву є найебективнішим $i$ окупним технологічним заходом із часткою умовно чистого прибутку у загальній вартості валової продукиї 10-79\% залежно від хімічного препарату. У середнъому частка витрат на хімічні засоби захисту рослин у технологї вирощування кукурудзи на зерно становить 8,5-23,1\%. За використання грунтових $і$ страхових гербіиидів складається вигідне співвідношення між вартістю валової продукиї та затратами на хімічні засоби захисту рослин від бур'янів. Рівень забруднення агроландшабту за внесення зазначеного асортименту гербіцидів є малонебезпечним. В технологї вирощування кукурудзи на зерно, найвищу економічну ефективність (мінімальна собівартість $1067 i 936$ грн/m, умовно чистий прибуток $32063 i 36027$ грн/га, рівень рентабельності 322 i $381 \%$ ) можна досягти зі внесенням грунтового гербіциду Харнес із додаванням страхових гербіцидів Каллісто 480 SC та Мілагро 040 SC.

Ключові слова: кукурудза на зерно, грунтові гербічиди, страхові гербічиди, агроекологічна оцінка, економічна ефективність.

Постановка проблеми. Однією із найрозповсюдженіших зернових культур у світі є кукурудза (Zea mays L.). За даними ФАО, за величиною посівних площ вона посідає третє місце у світі після пшениці і рису, а в Україні вона поступається лише пшениці та соняшнику.

За рахунок запровадження інноваційних розробок, зокрема сучасних високопродуктивних гібридів і хімічних засобів захисту рослин нового покоління вітчизняні агрогосподарства можуть отримувати врожаї кукурудзи на рівні провідних країн світу $[1,2]$. Це встановлено за позитивною динамікою зростання врожайності зерна кукурудзи в Україні: за 1990-2018 рр. урожайність збільшилася майже вдвічі і в 2018 р. становила 78,4 ц/га, та за оцінкою експертів має значний потенціал для подальшого підвищення.

Виділення невирішених раніше частин загальної проблеми. Незважаючи на низку екологічних ризиків, кукурудзу за беззмінного посіву або спрощених сівозмінах за широкого застосування хімічних засобів захисту рослин вирощують у багатьох країнах світу і наукові дослідження з питань екологічної безпеки та економічної доцільності залишаються актуальними. А отже, необхідно вживати заходів і запроваджувати різні агрозаходи, спрямовані на зменшення негативного впливу на нав- 
колишнє природне середовище й людину та мінімізувати витрати ресурсів на створення одиниці продукції.

Застосування засобів захисту рослин є невід'ємною складовою сучасних агротехнологій. Однак для мінімізування негативного впливу хімічних засобів захисту рослин на складові агроекосистеми та прилеглі території необхідно прораховувати екологічні ризики їх застосування, тобто ймовірність вияву їх екологічної небезпеки в реальних умовах природного середовища [3-5].

За наявності широкого і швидко оновлюваного асортименту гербіцидів виявлення найефективніших препаратів із найменшою негативною дією на навколишнє природне середовище та високою рентабельністю є важливим завданням, що й зумовлює актуальність даного дослідження.

Мета роботи - визначити агроекологічну оцінку та економічну ефективність вирощування кукурудзи на зерно за беззмінного посіву за різних систем захисту рослин, проаналізувати економічні показники й структуру виробничих витрат.

Матеріали та методи досліджень. Для проведення досліджень щодо агроекологічного оцінювання застосування різних гербіцидів за беззмінного посіву кукурудзи було закладено тимчасовий польовий дослід на Панфрильській дослідній станції ННЦ «Інститут землеробства HAAH» (с. Панфрили, Яготинський р-н, Київська обл.) упродовж 2016-2018 рр. із дотриманням відповідних рекомендацій [6-8]. Розмір ділянки: ширина - 7,0 м, довжина - 9,0 м. Посівна площа ділянки $63,0 \mathrm{~m}^{2}$, облікова площа - 50,4 $\mathrm{m}^{2}$. Розміщення варіантів досліду і повторень систематичне, повторення триразове. Грунт чорнозем типовий малогумусний з умістом гумусу в орному шарі 4,9\%, гідролізованого азоту - 90 мг/кг, рухомих фрорм фросфрору $\left(\mathrm{P}_{2} \mathrm{O}_{5}\right)-$ 160 і обмінного калію $\left(\kappa_{2} \mathrm{O}\right)-170$ мг/кг грунту; $\mathrm{pH}_{\text {сол. }}-6,3$.

Висівали середньоранній гібрид кукурудзи ДН Арго ФАО 260. Технологію вирощування кукурудзи застосовували відповідно до зональних рекомендацій і загальноприйнятих методик.

У системі захисту беззмінного посіву кукурудзи від бур'янів досліджували грунтові й страхові гербіциди, які широко використовують в Україні. Дослідження виконували у різних комбінаціях унесення гербіцидів: контроль (без внесення гербіцидів); захист лише зі внесенням грунтових гербіцидів Харнес (2,0 л/га), Стомп 330 (4,5 л/га) — для порівняння дії грунтових гербіцидів; захист лише з унесенням страхових гербіцидів - Каллісто 480 SC (0,2 л/га), Міла- гро $040 \mathrm{SC}$ (1,0 л/га), Діанат (1,0 л/га), Естерон 60 (0,8 л/га) - для порівняння дії страхових гербіцидів; різні комбінації внесення грунтового і страхового гербіцидів. Технологія внесення гербіцидів — наземне обприскування. Грунтові гербіциди вносили перед посівом кукурудзи, страхові гербіциди - у фразі 35 листків.

Для екотоксикологічної оцінки гербіцидів розраховували період напіврозпаду $\left(\mathrm{T}_{50}\right)$ досліджуваних хімічних препаратів [9], їх ступінь небезпеки $\left(\mathrm{C}_{\mathrm{H}}\right)$ та ризик застосування пестицидів за інтегральним показником агроекотоксикологічним індексом (AETI) [10]. Толерантність території до пестицидного навантаження оцінювали за величиною зонального індексу здатності самоочищення земельних угідь $\left(\mathrm{I}_{30 н}\right)$, який відображає інтенсивність деструкції пестицидів залежно від грунтово-кліматичних умов. Величина зонального індексу самоочищення для зони Лісостепу для чорноземів типових становить $\mathrm{I}_{\text {зон }}=0,55$.

Економічну ефрективність вирощування кукурудзи на зерно розраховували за вдосконаленою методикою, розробленою на основі сучасних методів розрахунку економічних показників $[11,12]$. Для об'єктивного оцінювання економічної ефективності досліджуваних засобів захисту рослин від бур'янів проведено оцінку економічних показників у середньому за три роки. Вартість валової продукції визначали у порівняльних цінах, які ухвалені для ведення бухгалтерської звітності, витрати на вирощування кукурудзи - за допомогою технологічних карт та нормативних матеріалів.

Викладення основного матеріалу дослідження. Під час розроблення системи заходів боротьби зі шкідливими організмами в агроекосистемі та застосуванні хімічних засобів захисту рослин важливо завчасно оцінити рівень ix потенційної небезпеки для навколишнього природного середовища й людини. Орієнтовні показники екологічної ситуації на певній території можна отримати, використовуючи математичну модель підсистеми «пестицид сільськогосподарський ландшафр» $[10,13]$.

Існує підхід, за якого застосовують розрахунковий метод оцінювання можливих негативних наслідків, що враховує гігієнічну і екотоксикологічну характеристики асортименту препаратів, кількісне пестицидне навантаження на навколишнє природне середовище та інтенсивність процесів деструкції пестицидів в умовах даного ландшафту [10, 14].

Для встановлення ступеня небезпеки $\left(\mathrm{C}_{\mathrm{H}}\right)$ застосування гербіцидів у системі захисту рослин кукурудзи використано інтегральну класифрікацію, яка враховує санітарно-гігієнічні $\left(\kappa_{\mathrm{A}}\right)$ 
і екотоксикологічні (КБ) показники небезпеки застосування пестицидів [10].

Клас небезпеки пестицидів за категорією А залежить від показника токсичності для теплокровних (ЛД 50 ). Згідно з офіційними даними [15], за показником токсичності досліджувані гербіциди розподілено на два класи небезпечності: препарат Харнес — зараховано до високо небезпечних (II клас), препарат Стомп 330 та страхові гербіциди Каллісто 480 SC, Мілагро 040 $\mathrm{SC}$, Діанат, Естерон - до помірно небезпечних (III клас) (табл. 1). Клас небезпеки пестицидів категорії Б залежить від їх персистентності, біокумуляції в об'єктах навколишнього природного середовища, фітотоксичної дії тощо і визначається за періодом напіврозпаду $\left(\mathrm{T}_{50}\right)$. Згідно з отриманими даними, досліджувані гербіциди розподілено на два класи небезпеч- ності за категорією Б - стійкі (II) і помірно стійкі (III).

Отже, згідно з інтегральною класифікацією препарат Харнес зараховано до небезпечних препаратів, решта гербіцидів за сукупністю екотоксикологічних і санітарно-гігієнічних показників - до помірно небезпечних.

Для оцінки та прогнозу рівня небезпеки забруднення агроландшафту гербіцидами нами використано модель екологічно безпечного використання пестицидів [10], яка включає середньозважену ступінь небезпеки пестицидів (Q), середнє навантаження пестицидів на територію господарства (Dект) та показник здатності території до самоочищення (Ізон). Результати розрахунків показників V, Q, Dект та на їх основі агроекотоксикологічного індексу (AETI) наведено в табл. 2.

Таблиия 1

Агроекологічна оцінка застосування грунтових і страхових гербіцидів

\begin{tabular}{|c|c|c|c|c|c|c|c|}
\hline \multirow{2}{*}{ Гербіцид } & \multirow{2}{*}{$\begin{array}{c}\boldsymbol{I}_{50}, \mathbf{м г} / \mathbf{~} \\
{[15]}\end{array}$} & \multirow{2}{*}{$\begin{array}{c}\text { Період } \\
\text { напів- } \\
\text { розпаду } \\
\left(\mathbf{T}_{50}\right)\end{array}$} & \multirow{2}{*}{$\begin{array}{c}\text { Перси- } \\
\text { стентність }\end{array}$} & \multicolumn{2}{|c|}{ Клас небезпечності за } & \multirow{2}{*}{$\begin{array}{c}\text { Ступінь } \\
\text { небезпеки } \\
\left(\mathbf{C}_{\mathrm{H}}\right) \\
\end{array}$} & \multirow{2}{*}{$\begin{array}{c}\text { Інтегральний } \\
\text { клас } \\
\text { небезпеки }\end{array}$} \\
\hline & & & & \begin{tabular}{|c|} 
категорією A \\
(KA)
\end{tabular} & \begin{tabular}{|c|}
$\begin{array}{c}\text { категорією } \mathbf{~} \\
\text { (КБ) }\end{array}$ \\
\end{tabular} & & \\
\hline Харнес & 1929 & 9,9 & Стійкі & II & II & 3 & $\begin{array}{l}\text { Небез- } \\
\text { печний }\end{array}$ \\
\hline Стомп 330 & 3189 & 10,2 & Стійкі & III & II & 4 & $\begin{array}{l}\text { Помірно } \\
\text { небезпеч- } \\
\text { ний }\end{array}$ \\
\hline $\begin{array}{l}\text { Каллісто } \\
480 \text { SC }\end{array}$ & $>5000$ & 4,7 & $\begin{array}{l}\text { Помірно } \\
\text { стійкі }\end{array}$ & III & III & 5 & $\begin{array}{l}\text { Помірно } \\
\text { небезпеч- } \\
\text { ний }\end{array}$ \\
\hline $\begin{array}{l}\text { Мілагро } \\
040 \text { SC }\end{array}$ & $>5000$ & 4,6 & $\begin{array}{l}\text { Помірно } \\
\text { стійкі }\end{array}$ & III & III & 5 & $\begin{array}{l}\text { Помірно } \\
\text { небезпеч- } \\
\text { ний } \\
\end{array}$ \\
\hline Діанат & 1581 & 11,6 & Стійкі & III & II & 4 & $\begin{array}{l}\text { Помірно } \\
\text { небезпеч- } \\
\text { ний }\end{array}$ \\
\hline Естерон 60 & 469 & 5,3 & Стійкі & III & II & 4 & $\begin{array}{l}\text { Помірно } \\
\text { небезпеч- } \\
\text { ний }\end{array}$ \\
\hline
\end{tabular}

Таблиия 2

Зведені дані розрахунків рівня небезпеки застосування гербіцидів

\begin{tabular}{|l|c|}
\hline \multicolumn{1}{|c|}{ Показник } & Розрахункове значення \\
\hline \hline Середньозважений ступінь небезпеки (Q) асортименту гербіцидів & 3,65 \\
\hline $\begin{array}{l}\text { Усереднене навантаження гербіцидів на територію } \\
\text { (екотоксикологічна доза) }\left(\mathrm{D}_{\text {ект }}\right), \text { кг га }\end{array}$ & 4,6 \\
\hline Забруднення ландшафту гербіцидами (V), умовних кг/га & 2,3 \\
\hline $\begin{array}{l}\text { Толерантність території до пестицидного навантаження } \\
\text { (індекс здатності самоочищення земельних угідь) }\left(\mathrm{I}_{\text {зон }}\right)\end{array}$ & 0,55 \\
\hline Агроекотоксикологічний індекс (АЕTI) & $\mathbf{0 , 1 6}$ \\
\hline
\end{tabular}


Відповідно до чотириступеневої градації небезпечності токсичних речовин, прийнятій у токсикології, розраховане значення AETI 0,16 свідчить, що рівень забруднення агроландшафту за застосування зазначеного асортименту гербіцидів у системі захисту рослин можна вважати малонебезпечним.

Економічну ефективність ведення агровиробництва в ринкових умовах має бути спрямовано на одержання максимальної кількості продукції з одиниці площі за найменших затрат праці і витрат матеріальних ресурсів на одиницю продукції. Тому під час визначення економічної доцільності застосування різних агрозаходів необхідно враховувати співвідношення між фактичними затратами та отриманим прибутком [16].

Аналіз економічних показників вирощування кукурудзи на зерно підтверджує про істотний вплив унесення гербіцидів у системі захисту рослин на собівартість, прибуток та рівень рентабельності (табл. 3). Значне коливання рівня врожайності кукурудзи впродовж років досліджень залежно від погодних умов та ефективності дії гербіцидів [17] обумовило різницю в показниках вартості валової продукції з одного гектара. Найвищим цей показник був у варіантах унесення грунтового гербіциду Харнес із додаванням страхових гербіцидів Каллісто 480 SC та Мілагро 040 SC, а також гербіциду Стомп 330 із додаванням Каллісто 480 SC і Мілагро 040 SC.

Одним із показників, які відображають економічну доцільність впровадження будьяких агрозаходів, є прибуток. Визначено, що найвищий відсоток умовно чистого прибутку у загальній вартості валової продукції становить $61-79 \%$, і одержано внесенням грунтового гербіциду Харнес із додаванням страховими гербіцидами.

Найвищий умовно чистий прибуток 32063 i 36027 грн/га та високий рівень рентабель-

Таблиияя 3

Показники економічної ефективності вирощування кукурудзи на зерно за беззмінного посіву за внесення різних гербіцидів, середнє за 2016-2018 рр.

\begin{tabular}{|c|c|c|c|c|c|c|}
\hline Варіант досліду & $\begin{array}{c}\text { Врожай- } \\
\text { ність, т/га }\end{array}$ & $\begin{array}{c}\text { Вартість } \\
\text { валової } \\
\text { продукції, } \\
\text { грн/га }\end{array}$ & $\begin{array}{l}\text { Виробничі } \\
\text { витрати, } \\
\text { грн/га }\end{array}$ & $\begin{array}{c}\text { Собівартість } 1 \text { т } \\
\text { прддукції, грн }\end{array}$ & $\begin{array}{c}\text { Умовно } \\
\text { чистий } \\
\text { прибуток, } \\
\text { грн/га }\end{array}$ & $\begin{array}{c}\text { Рівень } \\
\text { рента- } \\
\text { бельності, \% }\end{array}$ \\
\hline Контроль & 0,70 & 3150 & 6126,62 & 10367 & -4107 & -57 \\
\hline Харнес & 3,51 & 15795 & 7222,77 & 2366 & 7489 & 90 \\
\hline Стомп 330 & 2,76 & 12420 & 8053,06 & 3355 & 3159 & 34 \\
\hline Каллісто 480 SC & 5,42 & 24390 & 7733,42 & 1641 & 15497 & 174 \\
\hline Мілагро 040 SC & 3,79 & 17055 & 7114,63 & 2159 & 8873 & 108 \\
\hline Діанат & 2,00 & 9000 & 7038,96 & 4047 & 905 & 11 \\
\hline Естерон 60 & 2,02 & 9090 & 6837,98 & 3893 & 1226 & 16 \\
\hline $\begin{array}{l}\text { Харнес + } \\
\text { Каллісто } 480 \text { SC }\end{array}$ & 9,34 & 42030 & 8666,63 & 1067 & 32063 & 322 \\
\hline $\begin{array}{l}\text { Харнес + } \\
\text { Мілагро } 040 \text { SC }\end{array}$ & 10,11 & 45495 & 8232,79 & 936 & 36027 & 381 \\
\hline $\begin{array}{l}\text { Харнес + } \\
\text { Діанат }\end{array}$ & 5,19 & 23355 & 7861,92 & 1742 & 14314 & 158 \\
\hline $\begin{array}{l}\text { Харнес + } \\
\text { Естерон } 60\end{array}$ & 6,30 & 28350 & 7763,74 & 1417 & 19422 & 218 \\
\hline $\begin{array}{l}\text { Стомп } 330+ \\
\text { Каллісто } 480 \mathrm{SC}\end{array}$ & 6,48 & 29160 & 9256,52 & 1643 & 18515 & 174 \\
\hline $\begin{array}{l}\text { Стомп } 330+ \\
\text { Мiлагро } 040 \mathrm{SC}\end{array}$ & 6,78 & 30510 & 8819,75 & 1496 & 20367 & 201 \\
\hline $\begin{array}{l}\text { Стомп } 330+ \\
\text { Діанат }\end{array}$ & 3,08 & 13860 & 8563,94 & 3198 & 4011 & 41 \\
\hline $\begin{array}{l}\text { Стомп } 330+ \\
\text { Естерон } 60\end{array}$ & 3,38 & 15210 & 8389,37 & 2854 & 5562 & 58 \\
\hline
\end{tabular}




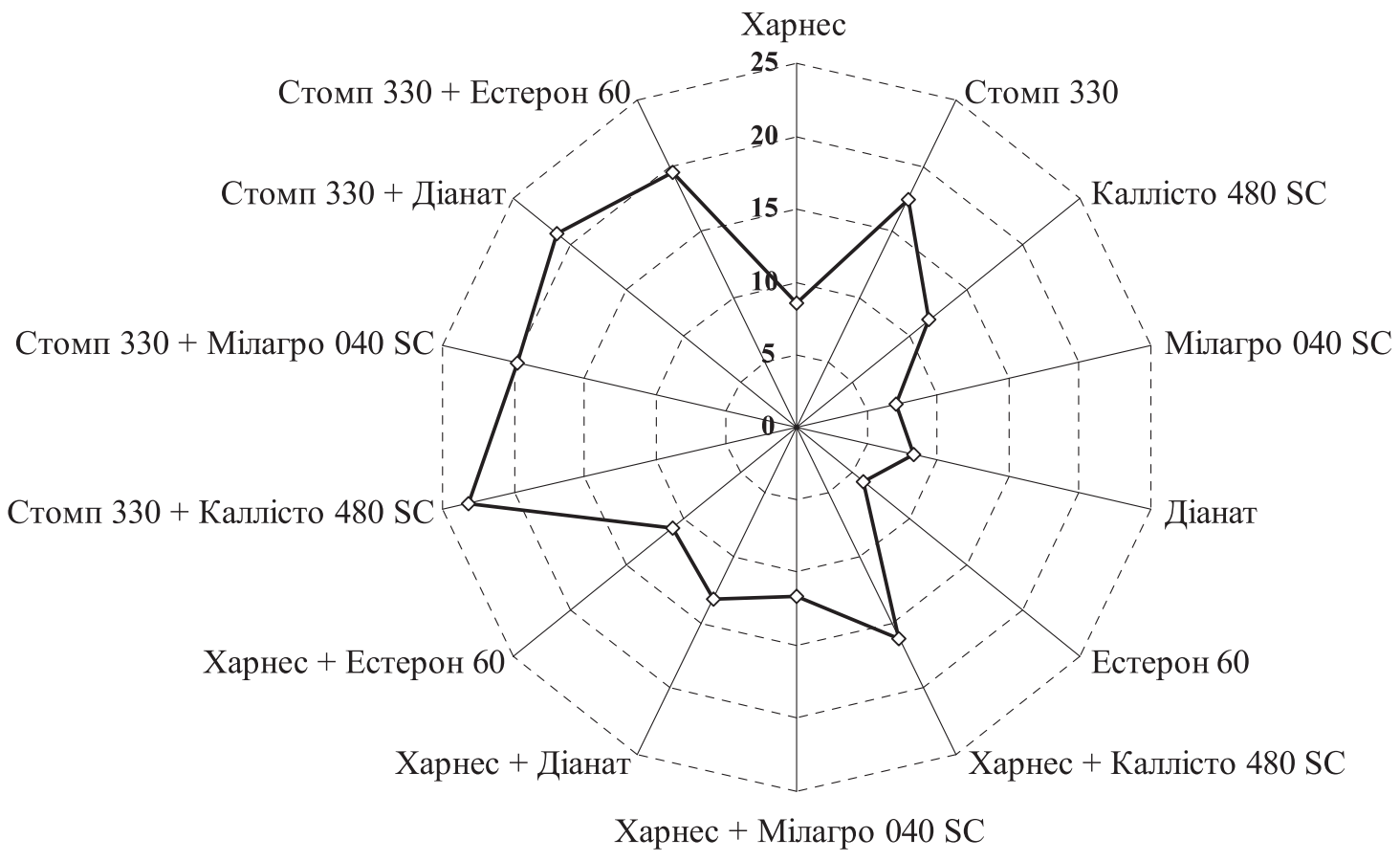

Частка витрат на хімічні засоби захисту рослин у технологї вирощування кукурудзи на зерно, \%

ності $(322,381 \%)$ отримано у варіанті Харнес + Каллісто 480 SC та Харнес + Мілагро 040 SC. Також за сукупністю економічних показників та порівняно низьким рівнем виробничих витрат унесення грунтового гербіциду Харнес із додаванням страхового гербіциду Естерон 60 сприяло одержанню прибутку 19422 грн/га і досягти рівня рентабельності $218 \%$.

Економічно вигідним також було вирощування кукурудзи на зерно за внесення гербіциду Стомп 330 із додаванням Мілагро 040 SC. У такій технології отримано врожайність 6,78 т/га та умовно чистий прибуток 20 367 грн/га, який становив $67 \%$ у вартості валової продукції.

За високого рівня забур'яненості вирощування кукурудзи на зерно за беззмінного посіву без застосування засобів захисту рослин проти сегетальної фітобіоти є економічно невигідним і збитковим. Низька врожайність [17], а відтак висока собівартість продукції свідчать про збитковість даної технології вирощування.

Неефективним було внесення лише страхових гербіцидів Діанат і Естерон 60. Висока вартість цих препаратів і низька ефрективність дії проти бур'янів у технології за беззмінного посіву позитивно вплинули на зростання собівартості 1 т продукції в 1,8-2,5 раза та зниження рівня рентабельності в $6,8-15,8$ раза порівняно з іншими страховими гербіцидами Каллісто 480 SC й Мілагро 040 SC. Аналогічно низькі показники умовно чистого прибутку й рівня рентабельності було отримано в технології застосування грунтового гербіциду Стомп 330 як окремо, так і з додаванням страхових гербіцидів Діанат і Естерон 60.

Аналіз структури витрат при вирощуванні кукурудзи свідчить, що основна частка витрат припадає на вартість паливно-мастильних матеріалів і мінеральні добрива - відповідно $16,0-22,2$ i $13,8-20,3 \%$. У структурі виробничих витрат частка на хімічні засоби захисту рослин від бур'янів у середньому становила $5,9-23,1 \%$ (рисунок). Найвищою вона була у варіантах із унесенням грунтового гербіциду Стомп 330 як окремо $(17,4 \%)$, так і з додаванням страхових гербіцидів (19,5-23,1\%).

Висновки. За сукупністю екотоксикологічних і санітарно-гігієнічних показників препарат Харнес зараховано до небезпечних препаратів, препарати Стомп 330, Каллісто 480 SC, Мілагро 040 SC, Діанат, Естерон 60 - до помірно небезпечних. За агроекотоксикологічним індексом (AETI) рівень забруднення агроландшафту за використання зазначених вище гербіцидів у рекомендованих дозах у посівах кукурудзи можна вважати малонебезпечним.

За високого рівня фрактичної забур'яненості посівів вирощування кукурудзи на зерно без застосування засобів захисту рослин проти сегетальної фітобіоти є економічно невигідним і збитковим. 
Застосування гербіцидів за беззмінного посіву є найефективнішим і окупним технологічним заходом із часткою умовно чистого прибутку у загальній вартості валової продукції 10-79\% залежно від хімічного препарату. У структурі виробничих витрат частка на хімічні засоби захисту рослин від бур'янів у середньому становила $5,9-23,1 \%$. За використання грунтових і страхових гербіцидів складається вигідне співвідношення між вартістю валової продукції та затратами на хімічні засоби захисту рослин від бур'янів.

Найвища економічна ефективність (мінімальна собівартість 1067 і 936 грн/т, умовно чистий прибуток 32063 і 36027 грн/га, рівень рентабельності 322 і $381 \%$ ) в технології вирощування кукурудзи на зерно досягнуто внесенням грунтового гербіциду Харнес із додаванням страхових гербіцидів Каллісто $480 \mathrm{SC}$ та $\mathrm{Mi}-$ лагро $040 \mathrm{SC}$.

\section{СПИСОК ВИКОРИСТАНИХ ДЖЕРЕЛ}

1. Цехмейструк М.Г., Музафаров Н.М., Манько К.М. Аспекти вирощування кукурудзи // Агробізнес сьогодні. 2014. № 8 (279). С. 28-33.

2. Черенков А.В., Циков В.С., Дзюбецький Б.В., Шевченко М.С. та ін. Інтенсифікація технологій вирощування кукурудзи на зерно - гарантія стабілізації урожайності на рівні $90-100$ ц/га: практ. реком. Дніпропетровськ: ДУ Інститут сільського господарства степової зони НААН, 2012. 31 с.

3. Влізло В.В., Салига Ю.Т. Проблеми біологічної безпеки застосування пестицидів в Україні // Вісник аграрної науки. 2012. № 1. С. 24-28.

4. Моклячук Л.І., Городиська I.M., Монарх В.В. Необхідність екотоксилогічної оцінки асортименту пестицидів при хімічному захисті сільськогосподарських культур // Вісник Житомирського національного агроекологічного університету. 2012. Вип. 1(30), т. 1. С. 232-237.

5. Моклячук Л.І., Кавецький В.М., Піскунова Л.Е., Каленська С.М. Екологічна оцінка небезпечності застосування пестицидів у сучасних технологіях вирощування зернових культур // Збірник наукових праць Інституту землеробства УААН. 1999. Вип. 3. С. 117-121.

6. Доспехов Б.А. Методика полевого опыта. Москва: Колос, 1985. 351 с.

7. Лебідь С.М., Циков В.С., Пащенко Ю.М. та ін. Методика проведення польових дослідів з кукурудзою. Дніпропетровськ, 2008. 27 с.

8. Методика випробування і застосування пестицидів. Трибель С.О., Сігарьова Д. Д., Секун М.П. та ін.; за ред. проф. Трибеля С.О. Київ: Світ, 2001. 448 с.

9. Stoytcheva M. Pesticides in the modern world. Pesticides Use and Management. Rijeka, Croatia: In Tech, 2011. $572 \mathrm{p}$.

10. Васильев В.П., Кавецкий В.Н., Бублик Л.И. Интегральная классификация пестицидов по степени опасности и оценка потенциального загрязнения окружающей среды // Агрохимия. 1989. № 6. C. $97-102$.

11. Манько Ю.П. Методичні рекомендації прогнозування забур'яненості посівів та еколого-економічне обгрунтування заходів захисту посівів від бур'янів. Київ, 1992. 18 с.

12. Медведовський О.К., Іваненко П.І. Енергетичний аналіз інтенсивних технологій в сільськогосподарському виробництві. Київ: Урожай, 1988. 208 с.

13. Бублик Л.І., Чергіна О.Д., Крук Л.С., Косматий В.С., Чоботько К.О. Систематичний аналіз пестицидів в зернових колосових культурах. Науковий вісник НАУ. 2005. № 90. С. 54-63.

14. Бублик Л.І. Теоретичні основи та методи моніторингу пестицидів в агроценозах: дис. ... д-ра с.-г. наук: 03.00.16. / Інститут захисту рослин УААН. Київ, 1995. 246 с.

15. Перелік пестицидів і агрохімікатів, дозволених до використання в Україні. Київ: Юнівест медіа, 2014. $832 \mathrm{c}$.

16. Ціноутворення та нормативні витрати в сільському господарстві (теорія, методологія, практика). Т. 1. Теорія ціноутворення та технологічні карти вирощування сільськогосподарських культур; за ред. П.Т. Саблука, Ю.Ф. Мельника, М.В. Зубця, В.Я. Месель-Веселяка. Київ, 2008. 698 с.

17. Шацман Д.О. Ефективне виробництво зерна кукурудзи за повторного вирощування та різних систем захисту в Лівобережному Лісостепу України // Вісник аграрної науки Причорномор'я. 2019. Вип. 1. C. $63-69$.

\section{Відомості про авторів}

Дем’янюк Олена Сергіївна - доктор сільськогосподарських наук, старший науковий співробітник, заступник директора з наукової роботи, Інститут агроекології і природокористування Національної академії аграрних наук України (Україна, 03143, м. Київ, вул. Метрологічна, 12; e-mail: demolena@ukr.net)

Шацман Дмитро Олександрович - здобувач, Інститут агроекології і природокористування Національної академії аграрних наук України (Україна, 03143, м. Київ, вул. Метрологічна, 12; e-mail: dmitry@evrosem.com). 
O.S. Demyanyuk

Doctor of Agriculture, Senior Researcher

Institute of Agroecology and Environmental Management of NAAS (Ukraine, Kyiv, e-mail: demolena@ukr.net)

D.O. Shatsman

Graduate Student

Institute of Agroecology and Environmental Management of NAAS (Ukraine, Kyiv, e-mail: dmitry@evrosem.com)

\section{AGROECOLOGICAL AND ECONOMIC ASSESSMENT OF THE APPLICATION OF SOIL AND POST EMERGENT HERBICIDES IN THE CULTIVATION OF CORN FOR GRAIN IN THE CONDITIONS OF THE LEFT-BANK FOREST-STEPPE OF UKRAINE}

Determined the agroecological assessment and economic efficiency of growing corn for grain in permanent sowing under various plant protection systems, to analyze economic indicators and the structure of production costs. In the conditions of the Left-Bank Forest-Steppe of Ukraine, in the technology of permanent sowing of corn for grain, the ecological and economic assessment of the application of soil (Harnes, Stomp 330) and post emergent (Callisto 480 SC, Milagro 040 SC, Dianat, Esteron 60) herbicides was determined. The hazard degree of the use of herbicides and agroecotoxicological index are calculated according to sanitary-hygienic and ecotoxicological indicators. The indicators of economic efficiency of technologies for growing corn for grain under various plant protection systems are calculated. According to sanitary-hygienic and ecotoxicological indicators, Harnes is classified as dangerous; Stomp 330, Callisto 480 SC, Milagro 040 SC, Dianat, Esteron 60 - are moderately dangerous. The use of herbicides in permanent crops is the most effective and cost-effective technological measure with a share of conditionally net profit in the total cost of gross output of 10-79\%, depending on the chemical preparation. On the average, the share of expenses for chemical plant protection products in the technology of growing corn for grain is $8.5-23.1 \%$. When using soil and post emergent herbicides, a favorable ratio is obtained between the cost of gross output and the cost of chemical plant protection products against weeds. The level of pollution of the agrolandscape when making the specified range of herbicides is low risk. It was determined that in the technology of growing corn for grain, the highest economic efficiency (minimum cost of 1067 and 936, $U A H / t$, conditionally net profit of 32063 and $36027 \mathrm{UAH}$ / ha, profitability of 322 and $381 \%)$ is achieved by applying the Harnes soil herbicide with the addition of an post emergent herbicides Callisto 480 SC and Milagro 040 SC.

Keywords: corn for grain, soil herbicides, post emergent herbicides, agroecological assessment, economic assessment

\section{REFERENCES}

1. Tsekhmeistruk, M.H., Muzafarov, N.M., Manko, K.M. (2014). Aspekty vyroshchuvannia kukurudzy [Aspects of corn cultivation]. Ahrobiznes sohodni [Agribusiness today], 8 (279), 28-33. (In Ukr.)

2. Cherenkov, A.V., Tsykov, V.S., Dziubetskyi, B.V., Shevchenko, M.S. et al. (2012). Intensyfikatsiia tekhnolohii vyroshchuvannia kukurudzy na zerno - harantiia stabilizatsii urozhainosti na rivni 90100 ts / ha: prakt. rekom. [Intensification of corn cultivation technologies for grain-guarantee of stabilization of yields at 90-100 c/ha: practical recommendations]. Dnipropetrovsk: DU Instytut silskoho hospodarstva stepovoi zony NAAN, 31. (In Ukr.)

3. Vlizlo, V.V., Salyha, Yu.T. (2012). Problemy biolohichnoi bezpeky zastosuvannia pestytsydiv v Ukraini [Some problems of biological safety of application of pesticides in Ukraine]. Visnyk ahrarnoi nauky [News of agrarian sciences], 1, 24-28. (In Ukr.)

4. Mokliachuk, L.I., Horodyska, I.M., Monarkh, V.V. (2012). Neobkhidnist ekotoksylohichnoi otsinky asortymentu pestytsydiv pry khimichnomu zakhysti silskohocpodarskykh kultur [The necessity of ecotoxicological valuing of pesticides assortment when carrying out chemical protection of agricultural crops]. Visnyk Zhytomyrskoho natsionalnoho ahroekolohichnoho universytetu [Journal Zhytomyr National Agroecological University], 1(30), 232-237. (In Ukr.)

5. Mokliachuk, L.I., Kavetskyi, V.M., Piskunova, L.E., Kalenska, S.M. (1999). Ekolohichna otsinka nebezpechnosti zastosuvannia pestytsydiv u suchasnykh tekhnolohiiakh vyroshchuvannia zernovykh kultur [Environmental assessment of the dangers of pesticide application in modern grain-growing technologies]. Zbirnyk naukovykh prats Instytutu zemlerobstva UAAN [Scientific works Institute of Agriculture of UAAS], 3, 117-121. (In Ukr.)

6. Dospekhov, B.A. (1985). Metodyka polevoho opyta [Methodology of the field experience]. Moskva: Kolos, 351. (in Russ.) 
7. Lebid, Ye.M., Tsykov, V.S., Pashchenko, Yu.M. et al. (2008). Metodyka provedennia polovykh doslidiv $z$ kukurudzoiu [Methods of conducting field experiments with corn]. Dnipropetrovsk, 27. (In Ukr.)

8. Trybel, S.O., Siharova, D.D., Sekun, M.P. et al. (2001). Metodyka vyprobuvannia i zastosuvannia pestytsydiv [Testing and application of pesticides]. Kyiv: Svit, 448. (In Ukr.)

9. Stoytcheva, M. (2011). Pesticides in the modern world. Pesticides Use and Management. Rijeka, Croatia: In Tech, 572 .

10. Vasilev, V.P., Kavetskiy, V.N., Bublik, L.I. (1989). Integralnaya klassifikatsiya pestitsidov po stepeni opasnosti i otsenka potentsialnogo zagryazneniya okruzhayuschey sredyi [Integrated classification of pesticides by hazard and assessment of potential environmental pollution]. Agrohimiya [Agricultural Chemistry], 6, 97-102. (In Russ.)

11. Manko, Yu.P. (1992). Metodychni rekomendatsii prohnozuvannia zabur'ianenosti posiviv ta ekoloho-ekonomichne obgruntuvannia zakhodiv zakhystu posiviv vid bur'ianiv [Methodological recommendations for predicting crop turbidity and ecological and economic justification of crop protection measures against weeds]. Kyiv, 18. (In Ukr.)

12. Medvedovskyi, O.K., Ivanenko, P.I. (1988). Enerhetychnyi analiz intensyvnykh tekhnolohii $v$ silskohospodarskomu vyrobnytstvi [Energy analysis of intensive technologies in agricultural production]. Kyiv: Urozhai, 208. (In Ukr.)

13. Bublyk, L.I., Cherhina, O.D., Kruk, L.S., Kosmatyi, V.Ye., Chobotko, K.O. (2005). Systematychnyi analiz pestytsydiv v zernovykh kolosovykh kulturakh [Systematic analysis of pesticides in cereals]. Naukovyi visnyk NAU [Scientific Bulletin of National Agriculture University of Ukraine], 90, 54-63. (In Ukr.)

14. Bublyk, L.I. (1995). Teoretychni osnovy ta metody monitorynhu pestytsydiv $v$ ahrotsenozakh: dysertatsiia doktora silskohospodarskykh nauk [Theoretical bases and methods of pesticide monitoring in agrocenoses: Doctor of Agricultural Sciences]. Kyiv: Instytut zakhystu roslyn UAAN, 246. (In Ukr.)

15. Perelik pestytsydiv i ahrokhimikativ, dozvolenykh do vykorystannia v Ukraini [List of pesticides and agrochemicals authorized for use in Ukraine]. (2014). Kyiv: Yunivest media, 832. (In Ukr.)

16. Sabluk, P.T., Melnyk, Yu.F., Zubets, M.V., Mesel-Veseliak, V.Ya. (2008). Tsinoutvorennia ta normatyvni vytraty $v$ silskomu hospodarstvi (teoriia, metodolohiia, praktyka). T. 1. Teoriia tsinoutvorennia ta tekhnolohichni karty vyroshchuvannia silskohospodarskykh kultur [Pricing and regulatory costs in agriculture (theory, methodology, practice). Vol. 1. The theory of pricing and technological maps of cultivation of crops]. Kyiv, 698. (In Ukr.)

17. Shatsman, D.O. (2019). Efektyvne vyrobnytstvo zerna kukurudzy za povtornoho vyroshchuvannia ta riznykh system zakhystu $\mathrm{v}$ Livoberezhnomu Lisostepu Ukrainy [Effective production of corn grain at the repeated growing and different systems of defence in Left-bank of Forest-steppe of Ukraine]. Visnyk ahrarnoi nauky Prychornomor'ia [Ukrainian Black Sea region agrarian science], 1, 63-69. (In Ukr.)

\section{Authors}

Demyanyuk Olena - Doctor of Agriculture, Senior Researcher, Deputy Director for Science, Institute of Agroecology and Environmental Management of National Academy of Agrarian Sciences of Ukraine (Ukraine, 03143, Kyiv, 12 Metrologichna St.; e-mail: demolena@ukr.net)

Shatsman Dmitry - graduate student Institute of Agroecology and Environmental Management of NAAS, of National Academy of Agrarian Sciences of Ukraine (Ukraine, 03143, Kyiv, 12 Metrologichna St.; e-mail: dmitry@evrosem.com). 